\title{
Run training ameliorates the established erectile dysfunction in rats under long-term nitric oxide (NO) blockade Mário A Claudino*1, Juliana S Baracat ${ }^{1}$, Enilton A Camargo1, Fernanda BM Priviero1 ${ }^{1}$, Cleber E Teixeira1 ${ }^{1}$, Gilberto de Nucci ${ }^{1}$, Angelina Zanesco ${ }^{2}$ and Edson Antunes ${ }^{1}$
} \author{
Physical Education, Institute of Bioscience (UNESP), Rio Claro, São Paulo, Brazil, 13506-900 \\ Email: Mário A Claudino* - mario.claudino@uol.com.br \\ * Corresponding author \\ from $3^{\text {rd }}$ International Conference on cGMP Generators, Effectors and Therapeutic Implications \\ Dresden, Germany. I5-17 June 2007 \\ Published: 25 July 2007 \\ BMC Pharmacology 2007, 7(Suppl I):PII doi:I0.II86/I47I-22I0-7-SI-PII
}

Address: ${ }^{1}$ Department of Pharmacology, Faculty of Medical Sciences (UNICAMP), Campinas, São Paulo, Brazil, $13084-971$ and ${ }^{2}$ Department of

This abstract is available from: http://www.biomedcentral.com/I47I-22I0/7/SI/PI I

(c) 2007 Claudino et al; licensee BioMed Central Ltd.

\section{Introduction}

Stimulation of nitrergic neurons and endothelial cells in the erectile tissue results in release of NO that diffuse to surrounding smooth muscle cells where it activates the soluble guanylate cyclase (sGC), facilitating the conversion of GTP to CGMP. This second messenger diminishes the intracellular levels of calcium thereby causing penile smooth muscle relaxation and penile erection [1]. Epidemiological studies have shown a strong association between erectile dysfunction (ED) and arterial hypertension [2], where the deficiency of the NO-cGMP pathway seems to greatly contribute to such association [3]. Regular physical exercise has been shown to increase the NO production thus ameliorating cardiovascular diseases $[2,4]$. Recently, we have shown that prior physical conditioning improves the erectile function in normotensive rats [5] and prevents the impaired corpus cavernosum relaxation secondary to chronic NO blockade in rats [2].

\section{Propose}

The aim of this work was to evaluate whether regular run training restores the established $\mathrm{ED}$ in made hypertensive by chronic treatment with the NO synthesis inhibitor LNAME.

\section{Methods}

Wistar rats were divided into control sedentary (C-SD), control trained (C-TR), L-NAME sedentary (LN-SD) and L-NAME trained (LN-TR) groups. Rats were treated with LNAME $(10 \mathrm{mg} / \mathrm{rat} / \mathrm{day})$ or tap water alone for 8 weeks. The run training program initiated after 4 weeks of LNAME treatment. It consisted in 4 weeks in a treadmill, 5 days/week, each session lasting $60 \mathrm{~min}$. The nitregic relaxing responses were evaluated by both electrical field stimulation (EFS) of corpus cavernosum in vitro and measurement of intracavernosal pressure (ICP) in response to electrical stimulation of the cavernous nerve (in vivo experiments). The plasma levels of nitrite/nitrate (NOx) were also measured.

\section{Results}

Physical exercise reduced significantly the L-NAMEinduced arterial hypertension $(103 \pm 4,95 \pm 3,154 \pm 7$ and $120 \pm 5 \mathrm{mmHg}$, mean arterial pressure for C-SD, CTR, LN-SD and LN-TR groups, respectively; $\mathrm{N}=8-12$ ). The in vitro and in vivo nitrergic-dependent relaxing responses were significantly reduced in LN-SD group compared with $\mathrm{C}-\mathrm{SD}$, as expected. The run training program significantly restored the in vitro EFS-induced relaxing response (Figure $1 \mathrm{a}$ ) and the in vivo erectile function (Figure $1 \mathrm{~b}$ and 1c). Plasma NOx concentrations were significantly reduced in LN-SD $(19 \pm 3 \mu \mathrm{M})$ compared with C-SD (28 


\section{Relaxation induced by electrical field stimulation}
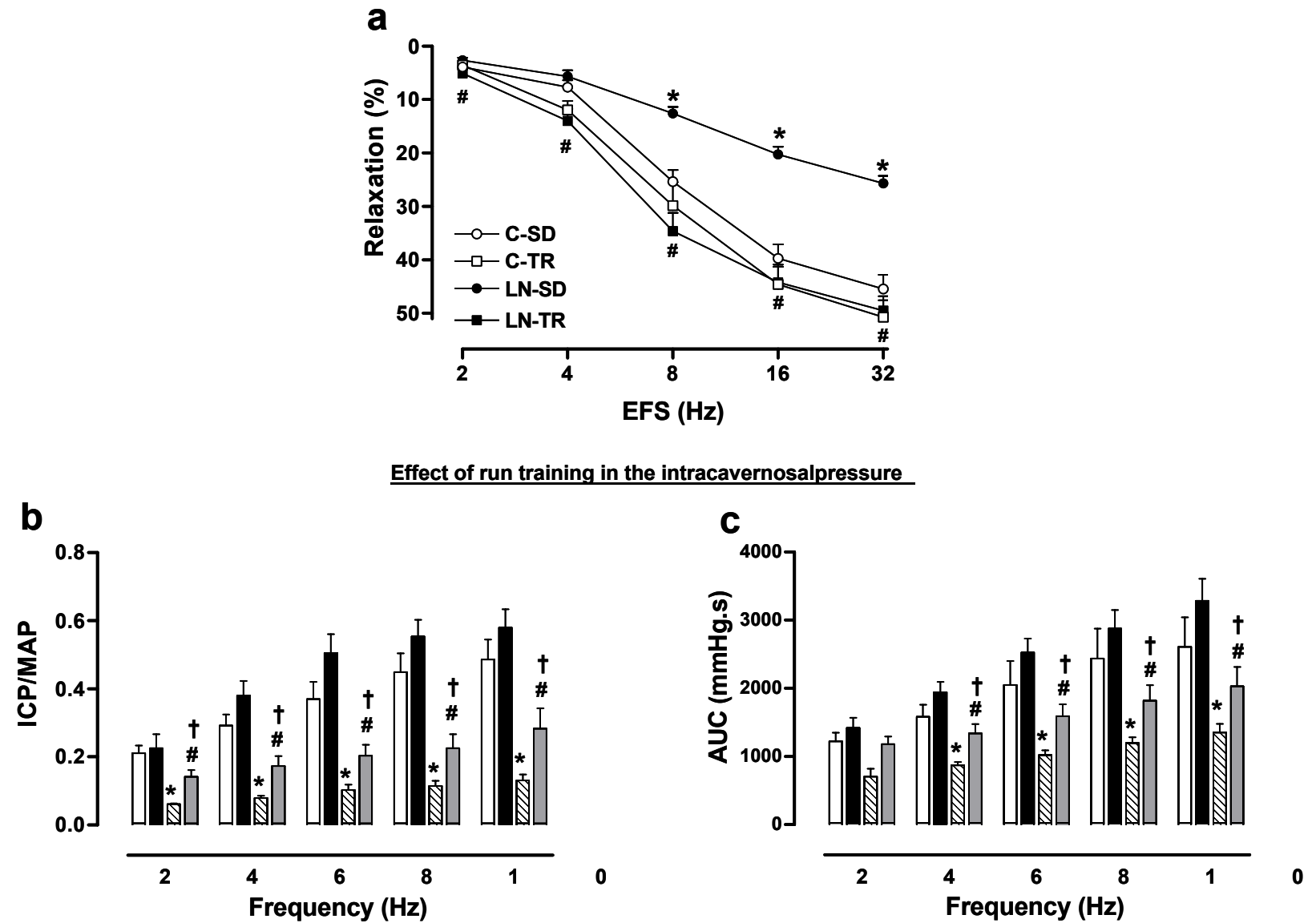

Figure I

Effect of run training in EFS-induced relaxing response $(2-32 \mathrm{~Hz}$; panel a) and erectile function induced by electrical stimulation of cavernosal nerve $(2-10 \mathrm{~Hz}$; panel $b$ and $c)$. Erectile function is expressed as the ratio ICP/MAP and area under the curve (AUC).

$\pm 2 \mu \mathrm{M})$. The run training program restored the NOx concentration in LN-TR group $(26 \pm 2 \mu \mathrm{M})$.

Experimental values were obtained from control sedentary (C-SD), control trained (C-TR), L-NAME sedentary (LN-SD) and L-NAME trained (LN-TR) animals. Data are mean \pm S.E.M of $4-8$ experiments. ${ }^{*} P<0.05$ compared to C-SD group; ${ }^{\#} P<0.05$ compared to $\mathrm{LN}-\mathrm{SD}$ group; ${ }^{\dagger} P<$ 0.05 compared to C-TR.

\section{Conclusion}

Our findings show that run training significantly reverses the established erectile dysfunction due to impairment of the NO-GMPc signalling pathway in rats.

\section{References}

I. Andersson KE, Wagner G: Physiology of penile erection. Physiol $\operatorname{Rev}$ 1995, 75:191-236.
2. Claudino MA, Priviero FB, Camargo EA, Teixeira CE, De Nucci G, Antunes $E$, Zanesco A: Protective effect of prior physical conditioning on relaxing response of corpus cavernosum from rats made hypertensive by nitric oxide inhibition. Int J Impot Res 2006, 19:189-195.

3. Burntt JC Jr: Coronary endothelial function in health and disease. Drugs 1997, 53(SuppI I):20-29.

4. Kingwell BA: Nitric oxide-mediated metabolic regulation during exercise: effects of training in health and cardiovascular disease. FASEB J 2000, 14:1685-1696.

5. Claudino MA, Priviero FB, Teixeira CE, de Nucci G, Antunes E, Zanesco A: Improvement in relaxation response in corpus cavernosum from trained rats. Urology 2004, 63: 1004-1008. 